\title{
Anatomi Kejahatan Korporasi di Indonesia Relevansi Studi Kejahatan Korporasi
}

\author{
Sri Suhartati Astoto
}

\begin{abstract}
The corporation growth as one of multi national company networks can not be avoided. Such as fialds of banks, export-import company, insurance, sailing and ect. The refletion of tehnology development in differnt fields, suchs as communication technology., informatics, create condusive condition for the development of corporation. According to the criminal law and criminology the portion of ecconomic law cares is complicated as the deviation in economic law as particular criminal action. The action in production and services, in intensive view point can interfere with in government program in economy but in extensive view point it can interfere with national economic system as privotal point of "pasal 3 UUD 1945". When the criminal action in economic law is performed by Corporation, it's impact is complicated, as it's position can be responsible to the criminal law (the suggestion for National Seminar on Criminal Corporation).
\end{abstract}

\section{Pendahuluan}

Perusahaan besar merupakan syarat utama bagi masyarakat industri modem, lepas dari bentuk organisasi sosial atau kepercayaan atau paham politik yang dianut dinegaranegara tertentu. Dewasa ini problem utama tiap masyarakat modern bukanlah: "Apakah ia menginginkan perusahaan besar, melainkan apa yang kita inginkan darinya, serta organisasi macam apa, dalam k̇aitan dengan masyarakat, yang harus dilayaninya bagi upaya mewujudkan cita-cita masyarakat sejahtera".'

Pada abad ke 20, para pakar ekonomi sudah "menyaksikkan" adanya pertumbuhan cepat badan-badan hukum multinasional. Perusahaan raksasa ini memproduksi sebagian besar produk barang dagangan dan memperkerjakan puluhan juta pekerja, mempengaruhi pilihan konsumen dan

'Peter F. Druker. 1972. Concept of the Corporation. New York: Mentor HIm 18. 
mendominasi sektor penting ekonomi dunia melalui operasi mereka secara global.

Sumber permodalan yang luar biasa besarnya, dengan berbagai variasi jenis perusahaan-perusahaan penting tersebut, memungkinkan mereka menggunakan maupun merubah teknologi secara besarbesaran. Dengan cara seperti itu, mereka telah memberikan konstribusi luar biasa kepada perkembangan perniagaan industri di negaranegara besar seperti Amerika Serikat, serta meluas hingga kepada regara-negara berkembang. Di Indonesia yang menuju Industrialisasi dan sedang tahap memasuki pelita $V$, tentunya berada dalam tarikan kemajuan dunia usaha yang diikuti oleh peranan korporasi yang sangat besar. Secara simultan dengan meningkatkannya kekuatan produksi besar perusahaan-perusahaan tersebut telah timbul pula potensi yang sama besar yang membahayakan masyarakat yang cenderung menjadi kenyataan.

Suatu gambaran yang ditemukan dalam suatu penelitian sekitar korporasi besar di Amerika Serikat menunjukkan adanya pelanggaran hukum secara besar-besaran yang mengakibatkan kerugiaan ekonomi yang cukup parah bagi konsumen dan terhadap negara, di samping cidera tubuh dan kematian beribu-ibu warga dan para pekerja sebagai akibat penggunaan obat-obat yang tidak aman, produk-produk lain yang dapat berakibat merugikan pemakai, kondisi kerja tanpa perlindungan, pencemaran lingkungan, penyelewengan pajak, dan lain-lain.
Banyaknya perbuatan-perbuatan illegal yang berakibat buruk yang sengaja dilakukan perusahaan terhadap konsumennya, para pekerjanya, persaingan merek dan bahkan terkadang mitra niaga bangsa-bangsa asing yang melibatkan ribuan dọlar dan apabila dijumlahkan secara kolektif bermilyar-dollar pertahun.2

Konstatasi dan kekuatiran akan keadaain seperti digambarkan dan tercermin pada uraian mengenai latar belakang pemikiran untuk penyelenggaraan Seminar Nasional Kejahatan Korporasi sebagai berikut:

a. Pertumbuhan korporasi sebagai salah satu jaringan perusahaan multinasional tidak dapat dihindarkan, antara lain di bidang perbankan, perusahaan imporekspor, asuransi, pelayaran dan sebagainya. Refleksi kemajuan teknologi diberbagai bidang misalnya teknologi komunikasi, informatika, menciptakan suasana konduktif untuk perkembangan korporasi.

b. Dari sisi hukum pidana dan kriminologi porsi perhatian terhadap hukum ekonomi semakin besar, sebab penyimpangan dalam hukum ekonomi yang merupakan tindak pidana dilihat sebagai sesuatu yang. istimewa. Tindak tersebut baik dalam produksi maupun jasa, dianggap dalam arti sempit dapat menggangu dalam program pemerintah dalam bidang ekonomi dan dalam arti luas dapat mengganggu sistem ekonomi nasional yang bersendikan Pasal 33 UUD 1945. Apabila

\footnotetext{
2Marshall B. Clinard and Yeanger Perer C. 1980. Corporation Crime the Free Press. A. Division of Mac Millan Publishing Co. Inc. HIm. IX.
} 
tindak pidana dalam hukum ekonomi tersebut dilakukan oleh korporasi dampaknya akan semakin besar, mengingat posisinya mampu untuk dipertanggung jawabkan dalam hukum pidana (usulan kegiatan untuk Seminar Nasional Kejahatan Korporasi UNDIP, 1989).

Clinard mengingatkan: "Interstingly, horever, comprate an business crimes senerally have not stimulated a sustained interst on the part of academic criminologists mot of whom have continued to concentrate on strest orimes, not orimes in the suites ${ }^{n}{ }^{3}$ Kecuali Sutherland dengan penelitian dan karyanya White Collar Grime, yang sudah empat puluh silam ikut serta menggugah perhatian para ahli untuk meneliti lebih lanjut white collar crime dan corporate crime. Seminar Nasional Kejahatan Korporasi yang diprakarsai UNDIP bekejja sama dengan partisipan yang terdiri dari para pakar dalam dan luar negeri kalangan Perguruan Tinggi serta instansi penegak hukum, merupakan "jawaban" atas tanda-tanda zaman yang dihadapi di masa mendatang. Relevansi seminar dan studi kejahatan korporasi dan jenis kejahatan lain yang serius sejalan dengan harapan dan kontribusi DR.G.A.A.J Van den Heuvel. "I hope, coferences like this convinces the autorities to reshift their budgetting towards more university research in criminilogy and criminal policy, but they lack basic materials decribing the strong an the weak sides of the actual criminal justice system. I hope this situations will be better in the near future".4

\section{Perkembangan Perhatian Masyarakat terhadap Kejahatan Korporasi}

Beberapa tahun terakhir ini istilah kejahatan korporasi (corporate crime) mulai diketahui dan dirasakan serta menarik perhatian masyarakat, lembaga-lembaga Pemerintahan dan pakar yang merasa prihatin terutama mengenai relatif kecilnya riset atas kejahatan badan hukum sejak Sutherland di tahun 1949.

Suatu penelitian sejarah tentang keprihatinan masyarakat terhadap kejahatan menunjukan bahwa keprihatinan tersebut telah mengkonsentrasikan beberapa periode pada kejahatan jalanan, kejahatan yang diorganisir, obat terlarang, dan pemerkosaan. Keprihatinan sosial ini tentu mempengaruhi badan legislatif dan badan-badan penegak hukum serta berpengaruh terhadap kencenderungan penelitian dalam bidang hukum, sosiologi dan kriminologi. Paparan sebuah hasil penelitian di Amerika Serikat mengenai text books dan laporan penelitian memberikan gambaran sederhana sebagai berikut:

Dari 28 text book yang membahas masalah sosial dalam kaitannya dengan kriminalitas yang diterbitkan antara 1964 1978 jumlah keseluruhan hanya sebanyak kurang lebih dari 10 halaman yang membahas pentingnya perhatian dan kewaspadaan masyarakat terhadap badan-badan hukum besar dan hanya 11 halaman dari tiap buku yang menguraikan kejahatan korporasi. Maka dapat dikatakan sejak Sutherland

\section{3/bid. HIm X}

'Dr. G.A.A.J. Van Den Heuvel. "New Trend In Criminology". Disajikan dalam Penataran Kriminologi tentang Perkembangan Kuasa Kejahatan. Semarang: UNDIP. 25-26 Oktober 1988. 
mempublikasikan White Collar Crime (1949), yang sebenarnya harus berjudul "Corporate Crime" sampai dengan tahun 1972 pembahasan kejahatan korporasi masih terhitung langka, demikian pengembangan selanjutnya dari penelitian Sutherland sangat terbatas. $^{5}$

Namun beberapa tahun kemudian terjadi peningkatan perhatian dan keinginan masyarakat untuk "mengenal" kejahatan korporasi yang oleh para krimonolog dianggap wajar. Gejala ini telah mengkontribusikan pemikiranpemikiran untuk meningkatnya perhatian dan rasa prihatin atas terjadinya kejahatankejahatan korporasi. Hal ini tercemin dalam berbagai artikel tentang kejahatan dan pelanggaran yang dilakukan oleh korporasi yang menyangkut bidang ekonomi, politik, lingkungan hidup dan lain-lain.

Cibsons \& Clintock mengklasifikasikan adanya tipe kejahatan sebagai berikut: ${ }^{6}$

1) Profesional thief

2) Profesional heavy criminal

3) Semi profesional property criminal

4) Property offender one time loser

5) Automobile joyrider

6) Naïve cheque forger

7) White collar crime

8) Profesional fringe violator

9) Embezzller

10) Personal offender

11) Psychopatic assaulist

12) Violent sex offender

13) Non-violent sex offender rape
14) Non-violent sex offender

15) Narcotic addict heroin

Konsep white collar crime dikembangkan untuk menunjukkan sekumpulan tindak pidana yang melibatkan tindakan pidana moneter dan ekonomi dalam arti luas yang pada masamasa sebelum Shuterland tidak lazim terkait dengan kriminalitas.

White collar crime di Amerika Serikat dan negara-negara yang telah memakai istilah ini dibedakan dari kejahatan sosio-ekonomi yang lebih rendah derajatnya dari struktur pelanggaran, di mana terhadap jenis kejahatan ini hukuman administratif dan perdata lebih sering digunakan sebagai hukuman dari pada pemindahan.

Ketika Shuterland mencetak ungkapan white collar crime ia memberi batasan sebagai tindak pidana yang dilakukan oleh mereka dari golongan kelompok sosio-ekonomi menengah atau atas sehubungan dengan jabatan mereka (1949), sedangkan Edelhertz (1970) mendifinasikan white collar crime sebagai tindakan illegal atau serangkaian tindakan illegal yang dilakukan dengan caracara non-fisik dan dengan penyembunyian atau tipu muslihat, untuk memperoleh ủang ataupun harta benda dan untuk memperoleh manfaat perorangan dalam dunia usaha. White collar crime terdiri atas dua tipe yaitu Okupasional dan badan hukum. Kejahatan Okupasional dilakukan sebagian besar oleh individu-individu sehubungan dengan okupasi mereka.

5Marshall B Clinard and Yeanger Peter C. Op. Cit. Him. 13.

${ }^{8}$ Roger Hood and Sparks Richard. 1978. Key Issues in Criminology World University Library. New York. HIm 132. 
Kejahatan jabatan ini meliputi pelanggaran hukum oleh para pengusaha, politisi, ketua serikat kerja, pengacara, dokter, ahli farmasi, karyawan yang mengelapkan uang perusahaan dan lain-lain. Kejahatan Korporasi meliputi tindak-tindak seperti: Penghindaran pajak pendapatan, manipulasi, dalam penjualan hasil produksi, kecurangan dalam reparasi peralatan mobil, dan televisi serta peralatan rumah tangga, penggelapan, cek kosong dan penggelapan dalam penjualan surat-surat berharga. Politisi dan pegawai negeri juga melakukan kejahatan jabatan, termasuk penyalahgunaan langsung atas dana pemerintah dan berbagai tindak penyimpangan yang lain. (Kasus-kasus korupsi).

Kejahatan korporasi diperlukan dengan cara kolektif yang sukar dibandingkan dengan perbuatan individu pribadi.?

Apabila suatu korporasi melanggar hukum dalam tindakannya yang mengatasnamakan badan hukum itu, merupakan kejahatan korporasi, namun apabila ia memperoleh keuntungan pribadi dalam melakukan kejahatan terhadap korporasi, seperti halnya dalam penggelapan dana-dana badan hukum itu merupakan kejahatan okupasi atau jabatan. Kejahatan akupasi bisa melibatkan lebih dari satu orang pejabat dari suatu badan hukum.

Kejahatan korporasi adalah perbuatan yang dilakukan korporasi yang dapat dijatuhi hukuman oleh negara, berdasarkan Hukum Tata Usaha Negara, Hukum Perdata dan Hukum Pidana.
Kejahatan korporasi dalam Undangundang Pidana Indonesia berarti kejahatan yang dilakukan oleh suatu badan hukum, suatu perseroan, suatu perserikatan orang atau yayasan yang tidak menutup kemungkinan terhadap tindakan tersebut dikenakan sanksi menurut hukum administrasi negara gugatan Perdata.

\section{Kejahatan Korporasi dan Aspek-aspek Kondisi Sosial}

Indonesia memiliki wawasan untuk mewujudkan dan memelihara "ketahanan nasional" yakni suatu kondisi yang dinamis yang ditandai oleh ketangguhan kehidupan bangsa sehingga senantiasa mampu mempertahankan diri dari segala macam bahaya yang ditimbulkan baik dari luar maupun dalam negeri sendiri.

Bahaya bisa berbentuk perusahaan kondisi alamiah (geografi, demografi, dan kekayaan alam) dan perusahaan kondisi sosial (aspek-aspek kondisi ideologi, politik ekonomi, sosial, budaya dan keamanan masyarakat); yang disebabkan oleh gangguan alam dan oleh gangguan manusia serta gangguan alam karena manusia. Faktor manusia dalam membentuk dan membina kondisi soial memegang peran penentu. Dalam konteks perkembangan ekonomi dan pembangunan yang pesat, maka telah diperhitungkan salah satu gangguan yang dapat membahayakan kehidupan masyarakat adalah dampak sampingan dari pembangunan sendiri dan antaranya adalah korporasi-korporasi yang

'Susan Shapiro. 1976. A Background Paper on White Collar Crime. Yale Law School. HIm.14. 
dalam operasi niaga raksasanya sadar atau yang berdampak luas dan dapat mengancam keselamatan bangsa. Pengalaman dan pelajaran yang ditemukan oleh negara-negara yang telah melakukan penelitian ilmiah mengenai kejahatan korporasi peringatan hal ini.

Salah satu contoh adalah illustrasi sebagai berikut: Salah satu dari cara kasus-kasus yang dipublikasikan mengenai pencemaran lingkungan yang secara potensial mempengaruhi kehidupan banyak orang, melibatkan Hooker Chemical, yaitu perusahaan Subsider Occidental Petroleum Corporation yang pada tahun 1980 telah melibahkan 21.000 ton bahan kimia Canal. dekat air terjun Niagara New York, selama tahun 1942 s/d 1953. Karena tak ada pemberitahuan dan peringatan dari perusahaan, maka disekitar itu dibangun tempat pemukiman rakyat. Di tahun 1978 penduduk daerah itu mulai mengeluh karena adanya bahan kimia yang timbul dipermukaan. Dalam gugatan sebesar $\$ 635$ milyar terhadap Ocodental dan anak perusahaannya Hooker; Negara bagian New York menuduh bahwa bahan kimia limbahan yang dibuang di tempat itu mengandung bahan yang diduga menyebabkan penyakit kanker, kerusakan kelahiran atau bayi cacad. Perubahan genetika dan kondisi merugikan yang akut dan kronis terhadap tubuh manusia dan yang merusak atau diduga merusak tanaman dan kehidupan hewan.8.
Contoh lain yang cukup mengundang perhatian adalah: Laporan tahun 1972 mengenai Occupational safety and Health menyebabkan bahwa sebanyak 100.000 kematian dapat terjadi tiap tahun karena penyakit-penyakit okupasi lingkungan pekerjaan. Para pekerja pabrik terbunuh atau cedera karena kèracunan bahan kimia Vinyl Chloride, Beryllium Silica, Lead, atau timah dan bahan kimia lain.

Badan-badan hukum besar yang memiliki perusahaan raksasa itu memiliki sumber dan dana dengan mana dapat memonitor bahaya industri dan mampu mencegahnya, namun mereka meremehkan kesehatan para pekerja agar dapat menghemat uang. ${ }^{9}$

Itulah contoh dari sekian banyak kejadian nyata yang dialami negara-negara industri $d i$ mana korporasi raksasa baik dengan sengaja atau tidak tertibat dalam tindak pidana yang berakibat berat.

Beberapa laporan penelitian membuktikan bahwa kejahatan korporasi adalah gejala dalam lingkup aspek ekonomi khususnya industrialisasi dan niaga raksasa yang mengiringinya. Maka sebuah lukisan abstrak sionis telah menjadi sampul buku karya Clinard and Yeager corporate crime, yang digambarkan dengan sosok tubuh dengan pakaian resmi yang mewah duduk didepan meja eksekutif. Sosok tubuh ini dengan kepala yang tidak ada mata, telinga, hidung dan mulut.

Orang bisa menafsirkan bahwa dalam kepala ini ada aspirasi dan motivasi untuk mengeruk keuntungan yang sebesar-besarnya

${ }^{9}$ Wall Street Journal. 29 April 1980. Hlm 12.

'Merton Mintz and Cohen S Jerry. 1976. Public and Private and How to Make Accountable. Bantam New York: Power Inc. HIm 335. 
melalui kegiatan usaha yang dilakukan oleh badan-badan hukum besar atau korporasi dengan tindakan dan perilaku yang tidak mudah dimengerti oleh awan, yang dapat dikategorikan sebagai tindak pidana, yang akibat dan kerugian yang ditimbulkan bahkan jauh bisa melebihi kejahatan konvensional (seperti perampokan, pembunuhan, yang dilakukan oleh pribadi-pribadi).

Agak berbeda dengan gambar abstraktif di Amerika Serikat dan Negara-negara Barat lain, sosok jasmani dengan kepala polos tanpa mata dan lain-lain itu ditopang oleh busana yang berbeda-beda, bisa pakaian formal perlente, bisa juga pakaian biasa seperti kemeja, kaos oblong dañ lain-lain. Abstraksionis-karikatunis ini melambangkan bahwa Korporsi ini seperti Yayasan, Perserikatan Orang, Perseroan dan badanbadan Hukum lain dapat terlibat dalam berbagai tindak pidana.

Adapun perbuatan mereka adalah cetusan aspirasi atau motivasi atau mungkin presi-presi tertentu dari korporasi (bukan cetusan rasa atau pikiran orang atau manusia insani). $\mathrm{Di}$ hadapkan dengan kondisi sosial yang meliputi berbagai aspek yaitu:

a. Ideologi-Politik

b. Ekonomi

c. Sosial-Budaya

d. Pertahanan dan Keamanan Masyarakat (bangsa)

Korelasi antara korporasi dan berbagai aspek kondisi sosial tersebut di samping mewarnai gejala sosial umum yang rutin dan wajar diantaranya juga melahirkan bentukbentuk kejahatan korporasi yang akan dipaparkan di bawah ini.
1. Kejahatan Korporasi di Bidang Ideologi Politik

Selama periode tahun 1950 - 1965, dalam massa pengisian kemerdekaan, Indonesia menghadapai berbagai gerakan-pembrontakan dari serikat organisasi, giolongan, aliran dan lain-lain, yang ingin mewujudkan aspirasi mereka dalam pemerintahan, seperti mendirikan negara yang bersifat kedaerahan, negara agama, negara berdasarkan Ideologi, (DI/ TIl, PRRI/PERMEST, G30 SPKI, dan lain sebagainya). Dalam mewujudkan aspirasi yang bertentangan dengan cita-cita pencapaian tujuan nasional, mereka melancarkan tindakan-tindakan kriminalitas yang menimbulkan korban jiwa dan harta benda rakyat. Organisasi atau golongangolongan tersebut telah dapat ditumpas, namun dalam kelompok-kelompok yang lebih kecil aspirasi-aspirasi yang tidak sejalan dengan tujuan negara prokklamasi 17-8-1945 itu, masih dicetuskan dalam tindakan kejahatan dimasa pembangunan dewasa ini, seperti kasusu-kasus pembajakan udara, pembantaian pos polisi, peledakan ditempat keramaian, peristiwa gerakan pengacau keamanan di Lampung dan lain sebagainya yang dituntut antara lain berdasarkan UU. No 11 PnPs 1963 tentang Pembrantasan Kegiatan Subversi. (Peristiwa-peristiwa pemberontakan/subversi sebelum tahun 1963, banyak mewarnai diundangkannya UU.No.11 PnPs tahun 1963).

2. Kejahatan Korporasi di Bidang Ekonomi

Di samping secara perorangan maka dijumpai pula korporasi ang melakukan 
tindak pidana yang dianggap merugikan perekonomian negara yang dapat dituntut berdasarkan Undang-undang N0. 7 Drt. 1955 tentang Tindakan Pidana Ekonomi dan berbagai ketentuan perundangundangan yang berhubungan dengan ekonomi dan keuangan seperti penyelundupan, uang palsu, penyimpangan pajak dan lain-lain. Demikian pula terhadap korporasi yang melakukan perbuatan-perbuatan yang sangat merugikan keungan dan perekonomian negara.serta menghambat pembangunan nasional; yang dapat dituntut berdasarkan UU No. 13 tahun 1971 tentang Pemberantasan Tindak Pidana Korupsi.

3. Kejahatan Korporasi di Bidang Sosial Budaya.

Tindak Pidana dan berbagai kejahatan yang menyangkut bidang sosial budaya dan dapat dilakukan oleh korporasi antara lain dalam perbuatan tindakan yang merugikan hak cipta, pencurian barang-barang peninggalan sejarah (purbakala) dan delik-delik yang berakibat luas termasuk merusak generasi muda dan pendidikan yaitu tindak pidana penyalahgunaan narkotika yang dituntut berdasarkan UU No.9 tahun 1976 tentang Narkotika. Delik ini juga berkait erat dengan tindak pidana ekonomi dan - subversi. Disamping itu juga korporasi juga dapat terlibat dalam kejahatan yang berhubungan baik dengan aspek ekonomi maupun budaya yang dapat dituntut berdasarkan UU No. 11. tahun 1980 tentang tindak pidana suap yang dianggap sebagai perilaku yang bertentangan dengan kesusilaan dan moral Pancasila yang dapat membahayakan kehidupan masyarakat dan bangsa.

4. Kejahatan Korporasi di Bidang Pertahanan dan Keamanan Negara

Korporasi mungkin pula dapat berperan dalam kejahatan yang dapat membahayakan aspek pertahanan dan keamanan negara. Namun tentunya sulit untuk mencari atau menangkap korporasi yang harus bertanggung jawab. Biasanya yang ditangkap individunya, seperti dalam kasus-kasus imigrasi yang dapat dituntut berdasarkan UU No.8 Drt. 1955 tentang Tindak Pidana Imigrasi dan berbagai ketentuan yang berhubungan, seperti dalam kasus-kasus pemalsuan paspor, imigran gelap dan lain-lain. Di tahun 1970an juga pernah dipublikasikan dalam media masa mengenai kejahatan yang berhubungan dengan spionase yaitu yang mengenai pembocoran dokumen geografi kelautan kepada negara asing yang dituntut berdasarkan UU No.11 PnPs 1963 tentang subversi dan ketentuan perundangan yang berhubungan.

Ditinjau dari perkembangan dan kecenderungan kondisi sosial, nampaknya Indonesia yang telah siap dengan segala konsekuensinya untuk memasuki siap lepas landas atau era industrialisasi pada Pelita VI, maka bahaya potensial yang mengancam kamtibmas dalam bentuk kejahatan korporasi adalah perilaku kriminal yang menyangkut ekonomi makro dengan berbagai dampaknya seperti yang tanda-tandanya dapat diketahui dan rasakan akhir-akhir ini yaitu: 
a. Pencemaran lingkungan oleh limbah industri dan berbagai alat hasil teknologi canggih.

b. Ancaman keselamatan dan kesehatan tenaga kerja atau buruh pada industriindustri besar.

c. Hasil produksi obat dan makanan yang tidak aman seperti kasus biskuit beracun yang berdampak pada issu keracunan makanan secara luas serta hasil-hasil industri dan iklan yang dibesar-besarkan yang dapat merugikan konsumen.

d. Berbagai bentuk penipuan dengan menyalahgunakan fungsi komputer.

e. Penyimpangan-penyimpangan di bidang perbankan, surat-surat berharga, dan jenis-jenis penyimpangan lain dibidang niaga modern.

f. Perilaku "membohongi", membodohi rakyat dengan menyalahgunakan "yayasan" ala YKAM (Yayasan Kesejahteraan Adil Makmur) dan penyimpangan dengan nama Yayasan termasuk dengan dalih pendidikan yang ternyata dikomersialkan.

g. Penipuan tenaga kerja

Kesemuanya dilakukan oleh korporasi dalam arti luas seperti yang dinyatakan dalam beberapa UU Pidana Indonesia yaitu badan hukum, perseroan, perserikatan orang dan yayasan.

\section{Kompotensi Peradilan}

\section{dan Pertanggungjawaban Pidana}

a. UU No. 7 Dit. 1955, tentang pengusutan, penuntutan dan Peradilan Tindak Pidana Ekonomi (LN No. 7 tahun 1955). Pasal 39 ayat (2) merumuskan: Jika tersangka adalah suatu badan hukum, suatu perseroan, suatu perserikatan orang atau yayasan, maka yang kuasa ialah pengadilan ditempat dimana badan hukum, perseoan, perserikatan, yayasan, itu berkedudukan atau mempunyai kantornya.

b. UU No. 11 PnPs 1963 Tentang Pemberantasan Kegiatan Subversi (Tertanggal 16 Oktober 1963) Pasal 17 merumuskan sebagai berikut:

(1) Jika suatu tindak pidana subversi dilakukan oleh atau atas nama suatu badan hukum, perseroan, perserikatan orang, yayasan, atau organisasi lainnya, maka tindakan peradilan dilakukan, baik terhadap badan hukum, perseroan, perserikatan, yayasan atau organisasi lainnya itu, baik terhadap mereka yang memberi perintah untuk melakukan tindak pidana tersebut atau yang bertindak sebagai pemimpin dalam perbuatan itu, maupun kedua-keduanya.

(2) Suatu Tindak Pidana Subversi dilakukan juga oleh atau atas nama suatu badan, perseroan, perserikatan orang, yayasan atau organisasi lainnya, jika tindakan itu dilakukan oleh orang-orangnya baik hubungan lain, bertindak dalam lingkungan badan hukum perseroan, perserikatan orang, yayasan atau organisasi lainnya itu, tanpa mengingat apakah orang-orang tersebut masing-masing tersendiri melakukan tindak pidana itu atau pada mereka bersama ada unsurunsur tindak pidana tersebut. 
(3) Jika tindakan peradilan dilakukan terhadap suatu badan hukum, perseroan, perserikatan orang, yayasan atau organisasi lainnya itu pada waktu penuntutan diwakili oleh seorang pengurus atau, jika ada lebih dari seorang pengurus oleh salah seorang dari mereka itu. Wakil dapat diwakils oleh orang lain. Hakim dapat memerintahkan supaya seorang pengurus menghadap sendiri di Pengadilan, dan dapat pula memerintahkan supaya pengurus itu dibawa ke muka Hakim.

(4) Jika tindakan peradilan, terhadap satu badan hukum, perseroan, perserikatan orang, yayasan, atau. organisasi lainnya, maka segala panggilan untuk menghadap dan segala penyerahan surat-surat penggilan itu ditujukan kepada pengurus atau di tempat tinggal kepada pengurus itu atau ditempat pengurus itu bersidang atau berkantor.

\section{Aspirasi, Motivasi dan Presi Kejahatan Korporasi $i^{10}$}

Aspirasi-aspirasi yang berorientasi pada kepentingan kelompok, golongan, agama, aliran dan paham politik yang tiak sejalan dengan Pancasila dan UUD 1945, tercetus dalam berbagai gerakan dan kegiatan yang diantaranya juga berupa tindak pidana yang merugikan dan membawa korban baik badani, keselamatan maupun harta benda warga masyarakat. Walaupun tindakan atau aksinya masih relatif kecil, namun dampaknya cukup terasa.

1. Motivasi ekonomi pada sementara korporasi untuk mengeruk keuntungan dan kekayaan besar-besaran dengan menimbulkan kerugian besar kepada warga masyarakat dan warga negara melalui perbuatan-perbuatan kejahatan terselubung dengan modus operandi yang halus, memanfaatkan tehnologi canggih, merusak mental pejabat merupakan kerawanan yang cukup menonjol selama satu dasa warsa terakhir dan diperkirakan akan berlangsung terus memasuki abad ke 21. Dalam hal ini korporasi besar harus mawas diri dan aparatur yang berhubungan harus waspada. Korban yang dapat timbul baik menyakut kerusakan sumber daya alam maupun sumber daya manusia. Kemungkinan kerugian akibat kejahatan korporasi bisa disebabkan oleh korporasi didalam negeri bisa pula sebagai akibat tindakan yang dilakukan oleh badan hukum negara lain dalam lintas niaga transnasional.

\footnotetext{
${ }^{10}$ a. Aspirasi, harapan, dan tujuan untuk keberhasilan pada masa yang akan datang

b. Motivasi, dorongan yang timbul pada diri seseorang sadar atau tidak sadar untuk melakukan tindakan atau perbuatan tertentu.

c. Presi, dari kata Pres yang berarti tekanan yang memaksa untuk melakukan tindakan atau perbuatan tertentu.

Lihat Kamus Besar Bahasa Indonesia Depdikbud. 1988. Balai Pustaka.
} 
Beberapa faktor dan konsekwensi dalam kompetisi dunia niaga besar telah mendapatkan beberapa korporasi atau badan hukum dalam posisi yang sulit. Kesulitan-kesulitan yang dialami korporasi besar dapat menjadi presi yang berat, sehingga korporasi melakukan cara niaga yang tidak terpuji termasuk diantaranya bentuk illegalitas dan kriminalitas. Beberapa kasus yang cukup menonjol adalah kemacetan dalam kredit Bimas, KPR, BTN dan real Estate.

2. Motivasi untuk mendapatkan keuntungan yang sebesar-besarnya; merupakan "dorongan" kuat, sehingga sementara korporasi dalam memutuskan strategi dalam operasi niaganya langsung atau tidak langsung dapat terlibat dalam kejahatan korporasi.

Dari sudut pandang dan teori ekonomi masalah penentuan keputusan dalam suatu korporasi dapat merupakan masukan bagi penelitian korporasi termasuk di Indonesia. Uraian di bawah ini mudah-mudahan bermanfaat.

Dua pandangan umum mengenai perilaku organisasional telah disesuaikan untuk menjelaskan kejahatan dunia usaha. Model tujuan rasional dan organik menitik beratkan pada hubungan antara perusahaan-perusahaan dan lingkungan ekonomi serta "politik" mereka. Dalam konteks perilaku ekonomi, model tujuan rasional menegaskan tujuan memperoleh keuntungan. Pentingnya maksimisasi memperoleh keuntungan dalam pengambilan putusan dalam dunia usaha telah ditetapkan dalam teori ekonomi. Tekanan pada keuntungan telah digunakan sebagai faktor tunggal yang paling memaksa, atau mengharuskan dibelakang adanya oleh penyimpangan industri besar, apakah itu mengenai penentuan atau penetapkan atau pemasangan harga-harga, menghancurkan persaingan atau produk yang keliru." Betapapun, khususnya bagi badan-badan hukum raksasa, yang dapat dikatakan mendominasi kehidupan ekonomi negara-negara maju peranan pertimbangan keuntungan dalam perilaku melawan hukum harus dikualifisir ke dalam dua aspek yang bertalian.

Pertama, berdasarkan alasan-alasan bahiwa perusahaan-perusahaan mungkin dimiliki dan dikembangkan berdasarkan tujuan ganda dan bukan sekedar keuntungan yang tinggi semata-mata. Kemungkinan tujuan-tujuan lain ini dapat juga menjadi penting perihal adanya genus korporasi.

Kedua, perusahaan mungkin juga bukan mencari keuntungan yang maksimal dan menahan resiko usaha di mana strategis memerlukannya, nariun sebaliknya mencari peringkat kepuasan dalam tingkat dan pertumbuhan keuntungan yang secara bergiliran akan memungkinkan korporasi mencapai tujuan-tujuan lain.

"C.H. Mc. Caghy. 1976. Devient Behaviour, Crime, Conflict, and Interest Groups. New York: Mac Millan. HIm. 218. 
Betapapun, cita-cita untuk meningkatkan atau mempertahankan keuntungan yang paling akhir merupakan faktor kritis pada penyimpangan korporasi dalam arti luas, mulai dari penolakan untuk memasang perlengkapan-perlengkapan pengontrol dan pengendali pencemaran atau polusi sehingga keputusankeputusan yang direncanakan dengan baik untuk membuat produk jelek yang mudah aus atau rusak dan harus cepat di ganti. ${ }^{12}$

Dalam konteks yang lebih kontemporer beberapa penulis telah menyelidiki bagai mana industri-industri tertentu, misalnya industri-industri obat dan kimia, digolongkan melalui dorongan saingan dan keuntungan yang kuat dan besar yang dikaitkan dengan permintaan akan perkembangan berkesinambungan mengenai produk baru. ${ }^{13}$ Berdasarkan kondisi ini tekanan untuk memalsukan data test, memasarkan produk baru sebelum khasiat sepenuhnya diketahui, atau melibatkan diri atau berkecimbung dalam tehnik-tehnik penjualan yang tidak etis, dapat membawa akibat malapetaka terhadap manusia dan lingkungannya.
Pertimbangan keuntungan tidak hanya akan menjurus kepada produk yang tidak aman namun juga bisa dipakai untuk membela dan dengan diam-diam mepertahankan kondisi kerja yang tidak aman. Contoh paling akhir ini diberikan kepada beberapa industri untuk memerangi adanya pembatasanpembatasan mengenai tingkat maksimum partikel atau debu kasar yang berterbangan di udara dapat ruang kerja. ${ }^{14}$ Penyelidikan atau industri yang dilakukan pertama tidak memandang kearah pengaruh bahaya potensial asbes atau diri para pekerja dan sebaliknya hanya memfokuskan pada cara penentuan biaya bagi industri yang terkena pembatasan-pembatasan tadi.

Sieber (1979) dalam penelitiannya telah menemukan bahwa struktur badan hukum transnasional suatu negara memberikan fasilitas untuk melanggar hukum yang sering berbentuk tindakan penghindaran Undangundang Nasional yang. "mengawasi" kemungkinan manipulasi oleh badan hukum lebih kecil atau ringan di negara-negara tertentu dan gerakan berupa operasi antara negara untuk menghindari undang-undang yang mengatur masalah standar proteksi pemburuan dan lingkungan. Kesulitankesulitan dalam mengadakan penyelidikan-

${ }^{12}$ Ferd J Cook. 1966. The Corrupted Land, the Social Morality of Modern American. New York: Mac Millan. HIm. 45.

${ }^{13}$ Richard Barnet and Ronald Muller. 1974. Multinational Corporation. New York: Simon and Schuster. LihatJohn E. Conclin. 1977. Illegal but not criminal, Business Crime in America. Prentice Hall: Eaglewood Cliffs.

${ }^{14}$ Swartz. "Joel Silent Killers at Work". In M.D. Erman and R.J. Lundmann. 1876. Corporate and Govermental Deviance Problems of Organization in Contemporary Sociaty. Oxford University Press. HIIm 116- 120. 
penyelidikan menganai ligalitas transnasional diluar negeri oleh negara-negara yang terkena dan masalah-masalah pertanggung jawaban badan hukum induk bagi perbuatan dan tindakan cabang-cabang di luar negeri, juga cenderung mendorong perbuatan-perbuatan kejahatan oleh badan-badan hukum transnasional di mana saja.

Suatu korporasi tentunya tidak dapat dihukum penjara, ia hanya dapat hukum denda, dengan demikian sanksi pidana penjara yang diterapkan sebagai pengawas terhadap tiap pelaku tindak pidana tidak terdapat dalam korporasi semata-mata tanpa perilaku perseorangan dalam badan hukum itu yang dapat dipertanggung jawabkan secara individual. ${ }^{15}$ Dengan kata lain tindak pidana tindak pidana sebagai penganiayaan, pembunuhan, pemerkosaan, sumpah palsu dan lain-lain yang melekat pada pribadi si pelaku tidak bisa dipertanggungjawabkan terhadap korporasi.

\section{Simpulan}

1. Kejahatan korporasi di Indonesia sudah lama ada namun belum pernah diadakan penelitian yang represintatif serta belum terdapat tulisan-tulisan mengenai kejahatan korporasi yang seharusnya bisa berpengaruh yang mendorong para penegak hukum untuk menganai kasuskasus kejahatan korporasi secara lebih terarah.

2. Salah satu upaya yang nampaknya masih bisa dilakukan untuk menanggulangi kekurangan dan kelemahan indonesia dalam studi dan penelitian kriminalogi, dihadapkan dengan masalah kriminalitas termasuk semakin terasa bahayanya kejahatan korporasi yang harus ditanggulangi secara proposional, adalah meningkatkan pengembangan apa yang disebut sebagai "The Goverment Criminology". o

\section{Daftar Pustaka}

Barnet; Richard and Ronald Muller. 1974. Multinational Corporation, New York: Simon and Schuster.

Clinard, marshall B and Yeanger Peter C. 1980. Corporatin Crime The Free Press. A.Divinision of Mac Millan Pblubishing Co. Inc.

Conclin, Jhon.E. 1977. Illegal but not criminal, Business Crime in America. Prentice Hall: Eaglewood Cliffs.

Cook, Ferd J. 1966. The Corrupted Land, The Social Morality of Modern America. New York: Mac Millan.

Druker, Peter. F. 1972. Oponcept of the Corporaton. New York: Mentor.

Hood, Roger and Sparks Richard. 1978. Key Issues in Criminalogy World University Library. New York.

Mc. Caghy, C.H. 1976. Devient Behaviour, Crime, Conflict, and Interest Groups, Mac Millan. New York.

${ }^{15}$ Marshall B Clinard and Yeanger Peter C. Op. Cit. HIm.16. 
Mintz, Merton and Jerry S, Cohen. 1976. Public and Private and How to make Accountable, Bantam New York: Power Inc.

1989. Usulan kegiatan untuk Seminar Nasional Kejahatan Korporasi. Semarang: UNDIP.

Shapiro, Susan. 1976. A Background Paper on White Collar Crime. Yale Law School.

Sleber, Ulrich. 1979.Criminal abuse of economi Power by Transnasional Enterprises; In Klause Tiedemant,
Multinationale unternehmen und Strafecht. Cologne Carl Heymanns.

Swartz. "Joel Silent Killers at Work". In M.D. Erman and R.J. Lundmann. 1976. Corporate and Govermannmental Deviance Problems of Organzation in Contemporary Society, Oxford University Press.

Van Den Heuvel, DR.G.A.A.J. "New Trends In Criminology". Disajikan pada penataran kriminalogi tentang perkembangan Kuasa Kejahatan. Semarang: UNDIP 25-26 Oktober 1988.

米米 